\title{
Mining the Deep Seabed: Is Malaysia Ready?
}

\author{
Nik Munirah Nik Fuad ${ }^{1}$, Wan Izatul Asma Wan Talaat ${ }^{1} \&$ Mohd Hazmi Mohd Rusli $^{2}$ \\ 1 Institute of Oceanography and Environment (INOS), Universiti Malaysia Terengganu, 21030 Kuala \\ Terengganu, Terengganu, Malaysia \\ ${ }^{2}$ Faculty of Syariah \& Law, Universiti Sains Islam Malaysia, 71800 Nilai, Negeri Sembilan, Malaysia \\ Correspondence: Nik Munirah Nik Fuad, Institute of Oceanography and Environment (INOS), Universiti \\ Malaysia Terengganu, 21030 Kuala Terengganu, Terengganu, Malaysia. Tel: 60-14-544-1934. E-mail: \\ nikmunirahfuad@gmail.com
}

Received: November 22, 2016

Accepted: December 29, $2016 \quad$ Online Published: January 19, 2017

doi:10.5539/ass.v13n2p107

URL: http://dx.doi.org/10.5539/ass.v13n2p107

\begin{abstract}
The mineral industry is expanding fast coinciding with the increase in demands. The depleting land-based minerals has led to the seeking of mineral resources especially from deep sea. Deep seabed minerals have high concentration of precious metal in comparison to land-based minerals. A lot of countries have started to explore and exploit the deep seabed minerals. Thus, it is necessary for Malaysia to commence on deep seabed mining exploration to reap its economic and technological benefits. Similarly, like land mining, the marine environment will face environmental degradation from deep seabed mining exploration. Being a State-party to the United Nations Convention on the Law of the Sea 1982 (UNCLOS 1982) and Convention of Biological Diversity 1994 (CBD), Malaysia has yet to develop a set of policies, regulations and laws related to deep seabed mining to mitigate its effect to the marine environment coinciding to the requirements of these conventions. The purpose of this study is to explore the preparedness of Malaysia to embark on exploration of deep seabed mining in areas beyond the national jurisdiction while observing the effects of deep seabed mining to the marine environment. The challenges in exploring the deep seabed mining as well as the relevant international and national laws related to deep seabed mining will also be observed in this study.
\end{abstract}

Keywords: deep seabed mining, environmental effect, United Nations Convention on the Law of the Sea 1982 (UNCLOS 1982), Convention of Biological Diversity 1994 (CBD)

\section{Introduction}

The oceans cover more than 70 percent of the surface of the Earth namely Pacific Ocean, Atlantic Ocean, Indian Ocean, Arctic Ocean and Southern Antarctic Ocean. Several geological processes occur in the oceans before the formation of mineral resources. There are vast quantities of marine minerals that can be found under the ocean such as the solid minerals comprising of gold, iron, rare earth elements, tins and the non-solid minerals including the fossil fuels, natural gas and petroleum.

The discovery of the high quality of minerals in the deep sea started in the late 19th century with the development of technologies that made possible for scientists to discover new mineral resources (Guntrip, 2003). Seabed mining and deep seabed mining are two different types of mining activities. Seabed mining is a process which extract minerals and resources from the seafloor. It involves the extracting of solid and non-solid minerals as earlier mentioned. Meanwhile, deep seabed mining is a process which extract minerals at the deep seabed ocean. It only focusses on extracting the three main groups of minerals namely Polymetallic Nodules, Cobalt-Rich Ferromanganese Crusts and Polymetallic Sulphides (Markussen, 1994).

\section{Deep Seabed Mining}

Deep seabed mining is a process of extracting minerals at the deep seabed ocean. Historically deep seabed minerals were said to be prospected and identified in the 1970s (Egorov, Elosta, Kudla, Shan, \& Yang, 2012) when there was an urgency of finding new resources of minerals apart from the land-based minerals. Hein, Mizell, Koschinsky \& Conrad (2013) stated that deep seabed mining has potential benefits compared to land mining. The deep seabed mining will be a new resource to the mining minerals. The deep seabed minerals are different and better than the land-based minerals as they can cater the current high technological demands globally. 
Unlike deep seabed minerals, the deposited land-based minerals do not contain concentrated different high grade metals. Hence, the minerals need to be mined at the different mine sites.

Activities involved in deep seabed mining will not impact human populations as the exploitation occurs deep in the ocean. In addition, there will be no harm to the labour force as the deep seabed mining operations use high technology to explore, exploit, extract and process the minerals. In contrast, land mining will result in negative impact to the earth's surface such as the imprints of roads, buildings, open large holes in the grounds and tons of waste rocks. These impacts will eventually disturb the animal and human population, as well as the ecosystem function and services.

\subsection{Deep Seabed Minerals}

The deep seabed minerals are important in the production of the electronics and green technology sectors i.e. in the making of smartphones, tablets, electric cars, wind turbines and batteries. The top demanded minerals found in the deep sea are Polymetallic Nodules, Cobalt-Rich Ferromanganese Crusts and Polymetallic Sulphides (Hein et al., 2013).

These minerals are valuable and possess different compositions. Polymetallic Nodules contain minerals such as manganese, nickel, iron, copper, cobalt, magnesium and titanium. Cobalt-Rich Ferromanganese Crusts contain cobalt, nickel, platinum, copper, titanium, tungsten and cerium. Meanwhile, Polymetallic Sulphides include minerals such as copper, lead, zinc, gold and silver. The high composition of minerals in each of deep seabed minerals makes them more preferable compared to the minerals found on land. It is also one of the reasons why the exploiters are willing to invest a lot of money to explore the minerals that are in the deep seabed.

\subsection{Areas of Exploration}

The International Seabed Authority (ISA) is an international organisation established under the UNCLOS 1982 that organise, regulate and control all mineral-related activities at the international seabed Area. The ISA has allocated several Areas for the exploration. These Areas have been found to contain a profusion of deep seabed minerals. The current Areas of exploration and the potential deep seabed minerals are shown in Table 1 (ISA, 2016) and in Figure 1.

Table 1. Exploration Areas for Deep Seabed Minerals

\begin{tabular}{cc}
\hline Areas & Minerals \\
\hline Pacific Ocean & Cobalt-Rich Ferromanganese Crust \\
Clarion-Clipperton Fracture Zone in the North Pacific Ocean (CCZ) & Polymetallic Nodules \\
South Pacific Ocean & Mineral Resources \\
Indian Ocean & Polymetallic Nodules \\
Mid-Atlantic Ridge along the Atlantic Ocean & Polymetallic Sulphides \\
South Atlantic Seamounts in the South Atlantic Ocean & Polymetallic Sulphides \\
\hline
\end{tabular}

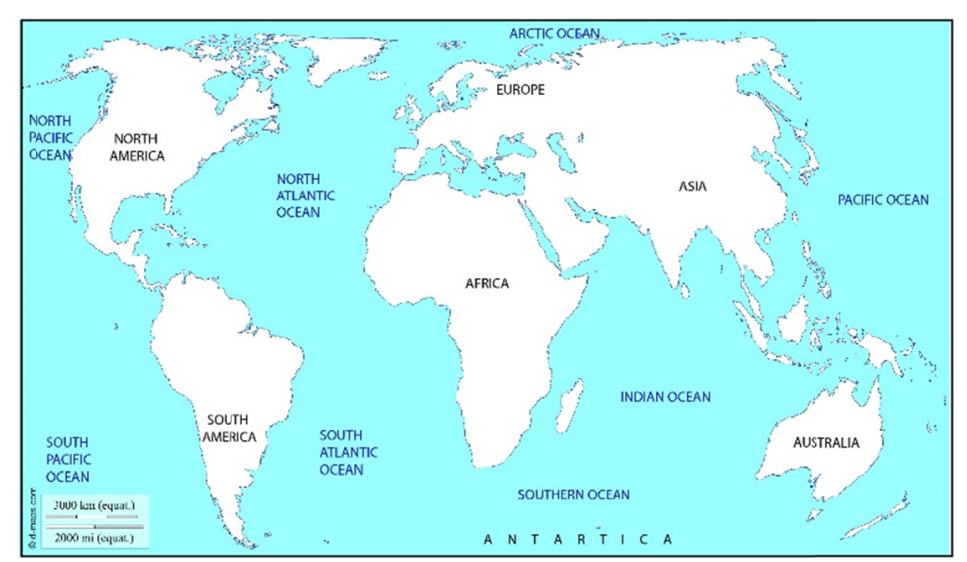

Figure 1. World ocean map (Source: Modified from d-maps.com, 2016) 


\subsection{Exploration Contracts}

Article 153 (2) of the UNCLOS 1982 stated that only State Parties, state enterprises or natural or juridical persons that possess nationality of State Parties can carry out activities in the international seabed Area. These entities or individuals must apply for an exploration licence. Article 153 (3) of UNCLOS 1982 explains that for an applicant to apply to the ISA for exploration contract, they must submit a plan of work to the ISA and obtain approval from the executive body of the ISA. The plan of work must include the capability of the applicant in terms of financial and technical abilities in exploring the deep seabed minerals. As stated in Article 139 under Part XI of UNCLOS 1982, Annex III of UNCLOS 1982 and also the International Tribunal for the Law of the Sea (ITLOS) Advisory Opinion 2011, countries that intend to apply for the exploration contract of deep seabed minerals from the ISA must have proper legislations to regulate the exploration activities. This is to ensure the liabilities of the contractors in the form of environmental damage are accounted for. From these legislations and statement, it advisable for a country to pass national legislations regarding deep seabed mining to ensure an effective enforcement has been done by the government.

As at August 2016, ISA has issued 25 licences for the exploration and exploitation of deep sea minerals to the governments and companies (ISA, 2016). The 15-year contract allow for mineral prospecting on over 2 million square kilometres of seabed in the Areas (Schmidt, 2015). Each area is limited up to 150,000 square kilometres. The top most countries that have been given licences to explore the deep seabed minerals are Russia, China, German, France, Republic of Korea and Japan.

\subsection{Exploration and Exploitation Technique}

The vast and unfamiliar environment of the deep sea ocean has made it difficult to be explored. Thus, the equipment and techniques of the exploration and exploitation of deep seabed minerals must be done by using high technology ships and machines.

\subsubsection{Exploration}

The deep seabed minerals can be explored and detected by remote sensing devices. This device will be send to the deep seabed to identify the depth and features of the seabed ocean by using the sound to assemble the data. Then, the sound data will be translated into a readable data. The exploration of deep seabed minerals will also need a machine called remotely operated vehicle (ROV). The video camera attached to the ROV will document the environment of the seabed. Couper (as cited in Warner, 2006) stated that the sunlight cannot penetrate through the ocean deeper than 200 metres of water depth. Naturally, in the deep seabed ocean only a little or no light at all can penetrate their depth. Therefore, a special light enhancing electronic is required to penetrate the dark environment deep in the ocean. With these equipment, the deep seabed minerals can be explored and detected for further exploitation.

\subsubsection{Exploitation}

The deep seabed mining process has no major differences compared to the land mining process except for the seabed mining process that must be carried out under water (ISA, n.d.-b). Allsopp et al. (2013) stated that basically, all seabed mining process will use the same techniques and methods. They include the process of extracting, lifting and processing the minerals. The minerals found on the deep seabed will be extracted or cut from the deep seabed using the mechanical or pressurised water drills. Then, they will be gathered and separated from the sediments. The lifting machine which probably will be using bucket, riser or pump techniques that will lift up the minerals to the surface of the sea and right into ship. On the ship, the extracted minerals will be processed by selecting the solid minerals which are marketable and will be compacted and stored. The selected minerals will then be transferred to the other ship and will be brought to the land for further process (Dyment et al., 2014).

\section{Effects of Deep Seabed Mining to The Marine Environment}

The effects of deep seabed mining to the marine environment had been researched since 1970s by several institutions namely the National Oceanic and Atmospheric Administration of the US, the German Ministry of Research and Technology and Japan's Metal Mining Agency (Markussen, 1994). The ISA has further conducted the research after its establishment in 1994 (Warner, 2006). Based on the research conducted, deep seabed mining can lead to several possible environmental effects to the marine environment.

\subsection{Water Pollution and Destruction of Habitat}

One of the possible effects is the water pollution. The water quality will degrade as a result of oil spills, hydraulic fluid leaks, or the ore spills during the extracting, lifting and processing the minerals. This might be 
worse if there is an unexpected accident that might occur during those processes. Equipment malfunction might also contribute to the water pollution (Birney et al., 2006). For example, if the lifting machine is not working, the ores that are being lifted will be lost to the seafloor. Thus, the sediment plumes will adversely impact the water quality near the seafloor (Hunter \& Taylor, 2013). These sediments will eventually smother the living organisms and destroy the habitat on the seafloor (Warner, 2016).

Apart from that, during the process of processing the minerals at the production support vessel, the minerals that are mixed with the seawater will be treated with different salinity and chemicals. The vessel during the process will then discharge the chemical water and sediments to the ocean and thus adding the possible impacts to the marine ecosystems (Mahapatra, 2014).

Besides, the habitat destruction will occur due to the machines used during the mining activities. The huge machines that are used to identify and extract the minerals will eventually cut and destroy the habitat on the seafloor.

\subsection{Vibration, Light and Noise pollution}

Levinton (as cited by Warner (2006)) in his book stated that the depth of seabed throughout the oceans varies which mainly started at the water depth of 200 metres and can be up to 11,000 metres. Deep seabed area is the deepest layer of the ocean. In this area, the living organisms livein darkness as the lights from the sun can only penetrate up to this level. Mining process will introduce light to the deep ocean. The lights from the machines will affect the feeding and reproductive behaviours of the deep ocean living organisms (Mahapatra, 2014).

During the exploration, the operating machines can transmit noises and vibrations in the ocean. The noises and vibrations can cause disturbance to the living organisms in the ocean. Living organisms such as whales and dolphins will suffer the most as they will lose communication signals between their species.

\section{Deep Seabed Minerals as the New Mineral Resources}

It is widely known that marine minerals are one of the major resources for mankind (Abdul, 2011). Marine minerals can be divided into two categories which are solid minerals and non-solid minerals. The heavy metallic solid minerals consist of barium, chromium, gold, iron, rare earth elements, tins, thorium, tungsten and zirconium. The non-metals solid minerals include diamonds, lime, siliceous sand and gravel. The non-solid minerals comprise of fossil fuels from decay, natural gas and petroleum (ISA, n.d.-a). Since land-based minerals resources are depleting, the world is now exploring for new mineral resources. (Sterk \& Stein, 2015). Deep seabed minerals are seen to be one of the new resources that can cater the worldwide demand on minerals.

Malaysia is blessed with abundant of natural assets. It has once become the largest producer and exploiter of land-based minerals such as tin and tropical timber in 1970s. Apart from that, Malaysia is also an active player in oil and natural gas industry, as well as other agricultural product such as natural rubber, palm oil, pepper, cocoa and marine fish (Vincent, 1997). Malaysia's source of income had depended largely on these resources especially the oil and natural gas (Othman \& Jafari, 2012). However, the land-based mining industry had become stagnant as the tin market had crashed in 1980s and due to lack of exploration and development of the land-based minerals (Lee, 2013). This has caused the country to focus more on the oil \& gas (O\&G) industry.

The oil \& gas (O\&G) industry in Malaysia has contributed up to $40 \%$ to the country's total revenues in terms of dividends, royalties and taxes. It has played a crucial role in the Malaysian economic development since the late 1980s (Othman \& Jafari, 2012). Nevertheless, the source of oil \& gas is depleting due to the impact of the production since the late 1980s (Lee, 2013). It is to be expected that in 30 years, the oil \& gas resources will be depleted (Mavani, 2012). A resource-rich country must substitute the depleting resources with the other new natural resources to maintain or increase their economic development (Vincent, 1997).

Malaysia aims to be a high-technology country. Thus, it is essential to have a continuous supply of minerals. With the depletion of land-based minerals, minerals found in the deep sea should be explored and mined. By embarking on the deep seabed mining, Malaysia will have the opportunity to seek new exploitable resources and establishes deep sea industry. In addition, Malaysia will be able to develop deep sea technology, geoscience, resource investigation, exploitation and processing technology as well as establishes the offshore support services (Aai, 2013).

\section{Preparedness of Malaysia to Embark on Deep Seabed Mining}

\subsection{Procedures to Explore DSM}

The ISA has established several rules, regulations and procedures to regulate the prospecting, exploration and exploitation activities of the deep seabed mining. These rules, regulations and procedures which is in accordance 
with Part XI of the UNCLOS 1982 is referred as the Mining Code (ISA, 2016). The rules and regulations set out by the ISA must be read together with the recommendations by the ISA's Legal and Technical Commission. This Code will guide the contractors on the assessment of the environmental effects of the deep seabed minerals exploration to the marine environment. Table 2 lists the regulations and recommendations in the Mining Code.

Table 2. The Regulations and Recommendations in the Mining Code

Recommendations Recommendations for the guidance of contractors on the content, format and structure
of annual reports ISBA/21/LTC/15
2) Recommendations for the guidance of contractors for the reporting of actual and direct
exploration expenditure ISBA/21/LTC/11
3) Recommendations for the guidance of contractors for the assessment of the possible
environmental impacts arising from exploration for marine minerals in the Area
ISBA/19/LTC/8
4) Recommendations for the guidance of contractors and sponsoring States relating to
training programmes under plans of work for exploration ISBA/19/LTC/14
1) Decision of the Assembly of the International Seabed Authority concerning overhead
charges for the administration and supervision of exploration ISBA/19/A/12
2) Decision of the Assembly of the International Seabed Authority relating to the
Regulations on Prospecting and Exploration for Cobalt-rich Ferromanganese Crusts in the
Area ISBA/18/A/11
3) Decision of the Assembly of the International Seabed Authority relating to the
Regulations on Prospecting and Exploration for Polymetallic Sulphides in the Area
ISBA/16/A/12/Rev.1
4) Decision of the Council of the International Seabed Authority relating to amendments
to the Regulations on Prospecting and Exploration for Polymetallic Nodules in the Area and
related matters ISBA/19/C/17
5) Decision of the Assembly of the International Seabed Authority regarding the
amendments to the Regulations on Prospecting and Exploration for Polymetallic Nodules in
the Area ISBA/19/A/9

In the Mining Code, there are several procedures that need to be fulfilled by the contractors before they embark on the exploration and exploitation of deep seabed minerals. The contractors must apply for approval plans of work for exploration in the form of contract that has been prescribed in the Regulations. However, before the contractor drafts the 15-year plan of work, they must first identify which type of the deep seabed minerals and which part of the Area they want to explore.

In the plan of work, the applicant must include the specific and sufficient information of the financial and technical capabilities of carrying out the proposed plan of work. This is crucial as the ISA will determine the capability of the contractor to fulfil the financial obligations to the Authority during the period of 15 years of the contract.

Apart from that, the applicant must include a general description and schedule of the proposed plan of work. The data and information cover the programme of activities for the first five-year period, the research and studies that will be done in respect to the marine environment, possible impacts of the exploration activities to the marine environment, proposed measures for the prevention and control of the potential environmental impacts. The technical, economic and other related factors should also be considered in the exploration. If the executive body of the ISA approves the plan of work, the ISA will grant the applicant the contract to explore and the contractor then shall start their exploration at the designated Area.

These procedures need to be done by the contractor before they embark on the deep seabed mining exploration. Therefore, if Malaysia want to explore the deep seabed mining activities, Malaysia must first identify which type of minerals and which Area do they want to explore. Apart from that, Malaysia have to ensure the financial and technical capabilities to embark on the exploration. A detail plan of work must be done before applying for the contract of exploration.

\subsection{The Duty to Enact DSM Laws}

All States have the responsibility to ensure that activities which are under their control and jurisdiction do not 
cause harm to the marine environment beyond the national jurisdiction (Anton, 2010). This has been clearly highlighted under UNCLOS 1982 where Article 192 provided that "the States have the obligation to protect and preserve the marine environment". The States have a "duty to prevent, reduce and control pollution from any source" (Article 194(1) of UNCLOS 1982). The States also have a "duty to take measures to protect and preserve rare or fragile ecosystems as well as the habitat of depleted, threatened or endangered species" (Article 194(5) of UNCLOS 1982). The States are required "to assess the potential effects of planned activities under States jurisdiction or control which may cause substantial pollution or significant and harmful changes to the marine environment" (Article 206 of UNCLOS 1982).

Many researchers have emphasised on how important it is to keep the marine environment safe especially in the deep seabed Area and the possible impacts of deep seabed mining to the marine environment. Marine scientists and environmental activists all around the world are concerned on how the deep seabed exploration and exploitation can give a major impact to the marine environment and to the world. However, the effects of deep seabed mining activities to the marine environment can be controlled if there are a set of legislations or rules with a proper mitigation measures to conserve and sustain the marine environment that govern these activities. This has been supported by a diamond mining company, Panda Marine in a magazine article by Burger (2014) where it claims that the environmental impact of deep seabed mining can be reduced if the mining activities were held responsibly and controlled.

One of the requirements for the States to explore the deep seabed mining is that the States must have a legislation with regards to the seabed mining which comply with the obligations established by the UNCLOS 1982 and ISA Mining Code. This has been stated in Article 139 under Part XI of UNCLOS 1982, Annex III of UNCLOS 1982 and the ITLOS Advisory Opinion 2011 where it can be summarised that the States must have certain national legislations with regard to seabed mining to ensure them to have an effective implementation and enforcement of administrative measures to conserve the marine environment. The explorer and exploiter of deep seabed minerals must apply precautionary approach while exploring and exploiting. Thus, by passing a certain set of rules and legislations on deep seabed mining, it will secure the explorer an exploiter to apply the best environmental practice. The legislations then must be read together with other international legislations such as the Convention on Biological Diversity 1992 (CBD 1992) in order to protect the marine biodiversity.

The number of contracts for exploration of deep seabed minerals seemed to be on the increasing trend. The deep seabed mining industry will emerge as a big industry as it is expected to be profitable to the exploiters. Malaysia has shown interest in joining the deep seabed mining exploration (Aai, 2015). However, Malaysia has yet to propose a set of specialised legislations or regulations on deep seabed mining beyond its national jurisdiction. In fact, there is no law related to deep seabed mining enacted in Malaysia as yet except for the definition term of "seabed" in several legislations.

It is important for Malaysia to enact a set of rules and legislations related to deep seabed mining beyond its national jurisdiction. This is to show to the world that Malaysia is committed in protecting the marine environment while exploring the seabed ocean.

\subsection{Related Mineral Mining Policies and Laws in Malaysia}

Being a State-party to the UNCLOS1982, and CBD 1992, Malaysia has to develop a set of policies, regulations and laws related to the deep seabed mining to mitigate its effect to the marine environment as outlined by these two conventions. In conserving the marine environment during the exploration of deep seabed mining, a proper and effective policies, regulations and laws must be in place.

In Malaysia, there is no specific legislation on deep seabed mining that spells out the mitigation measures to protect or to minimize the impact of deep seabed mining to the marine environment. Currently there are several laws and policies in Malaysia that may be important and related to seabed mining. However, some of these laws and policies only mention about the seabed in the definition section which they define one of the sources of minerals come from seabed. Therefore, they are not the primary legislations that govern the deep seabed mining activity. The existing legislations and policies are listed in Table 3.

If good and comprehensive laws were drafted to regulate the deep seabed mining, Malaysia could contribute with respect to sustainability of the environment in deep seabed mining industry. The marine ecosystems will be better protected and conserved. In drafting laws and policies on deep seabed mining, it is vital to analyse the impact of deep seabed mining on the marine environment. Related international and national policies, regulations and laws on deep seabed mining must be carefully studied. 
Table 3. Malaysian Laws and Policies Related to Mineral Mining

\begin{tabular}{|c|c|c|}
\hline & Laws and Policies & Details \\
\hline 1) & $\begin{array}{l}\text { Mineral Development Act } \\
1994\end{array}$ & $\begin{array}{l}\text { This Act came into force in August } 1998 \text {. It is the primary legislation regarding } \\
\text { mining activities. It defines the power of the Federal Government to govern } \\
\text { matters pertaining the inspection, exploration and mining of minerals and other } \\
\text { related issues. }\end{array}$ \\
\hline 2) & $\begin{array}{l}\text { Petroleum Mining Act } \\
1966\end{array}$ & $\begin{array}{l}\text { This Act provides for the provision related to petroleum mining and other matters } \\
\text { related. It governs the Malaysian oil and gas industry. }\end{array}$ \\
\hline 3) & $\begin{array}{l}\text { Petroleum Development } \\
\text { Act } 1974\end{array}$ & $\begin{array}{l}\text { It came into force after the development of the oil and gas industry in } 1974 \text {. This } \\
\text { Act gives the authority to Petroliam Nasional Berhad (PETRONAS), a } \\
\text { government-linked company to exercise exclusive ownership right to the oil and } \\
\text { gas resources in Malaysia. }\end{array}$ \\
\hline 4) & Continental Shelf Act 1966 & $\begin{array}{l}\text { This Act which was amended in } 2009 \text { regulates the exploration and exploitation } \\
\text { of its natural resources that includes the seabed and subsoil submarine areas. The } \\
\text { area of continental shelf are areas beyond the territorial sea of Malaysia to a } \\
\text { distance of } 200 \text { nautical miles. }\end{array}$ \\
\hline 5) & $\begin{array}{l}\text { Malaysian Maritime } \\
\text { Enforcement Agency Act } \\
2004\end{array}$ & $\begin{array}{l}\text { It came into force which gave the authority to the Malaysian Maritime } \\
\text { Enforcement Agency to act as a 'coast guard' to ensure the safety and security of } \\
\text { the Malaysian Maritime Zone (Ooi, 2007). }\end{array}$ \\
\hline 6) & Territorial Sea Act 2012 & $\begin{array}{l}\text { Provides for the breadth of the territorial sea of Malaysia up to a limit of } 12 \\
\text { nautical miles as well as the regulations for matters related. }\end{array}$ \\
\hline 7) & $\begin{array}{l}\text { National Biodiversity } \\
\text { Policy } 1998\end{array}$ & $\begin{array}{l}\text { This policy aims to conserve the biodiversity of Malaysia and to ensure the } \\
\text { sustainability of its components for the development of Malaysia's } \\
\text { socio-economic activities. }\end{array}$ \\
\hline 8) & National Mineral Policy 2 & $\begin{array}{l}\text { This policy was introduced in } 2009 \text { to enhance the mineral sector's role in the } \\
\text { development of socio-economic of the country. Although this policy had } \\
\text { encouraged the government to increase the mineral sector by discover mineral } \\
\text { resources at the offshore, it is only limited to known resources and not a new and } \\
\text { unknown resources (Aai, 2013). }\end{array}$ \\
\hline
\end{tabular}

\subsection{Challenges to Explore}

The challenges to explore the deep seabed mining can be in many forms. The lack of understanding of deep sea environment can lead to major problems. Deep sea area is a place which is full of mystery. It is not an area which the human is familiar with due to its depth. Since the exploration takes place at the deep sea, it requires a lot of data from the deep sea area. The knowledge of deep sea's environment and ecosystems are vital in providing best practices for the protection and safety to the marine environment. It is also fundamental in managing the deep ocean resources so that it can be enjoyed by the future generations.

However, the knowledge of the deep sea environment and ecosystems remain limited. This limitation is due to the expertise, financial and technological constraint. The deep sea exploration requires high end technological equipment, machines and ships. Apart from that, since the deep sea minerals are different in forms and nature, each of them require different mining techniques and equipment to cope with their particular habitat and environment (World Economic Forum, 2016). These will eventually lead to the extremely high cost exploration. According to Shailesh Nayak the secretary of Indian Ministry of Earth Sciences in 2014, the basic exploration will cost more than USD 89 million (RM 360 million) whereby the ships will cost around USD 29 million (RM 120 million) and the technologies will cost around USD 59 million (RM 241 million). The minerals that have been mined will then be processed at the process plant. The process include mixing, separating, packaging, transforming or changing the minerals before they are ready for the export market. The cost of these processes is estimated to be around USD 135 million (RM 544 million) (Mahapatra \& Chakravartty, 2014).

Apart from that, the exploration needs a huge commitment and efforts from all involved. The government, the stakeholders, researchers, legal and technical experts must sit together to develop a strategy in forming a good system in embarking the deep seabed exploration. In embarking the exploration, Malaysia will have to produce the legal and technical experts in handling the exploration. Apart from that, if Malaysia plans to collaborate or sponsor a company to explore, Malaysia will have to invest a huge amount of money. Besides, they have to prove in the 15-year plan of work, their financial is stable or else the application for the exploration contract will be not be considered by the ISA. Thus, Malaysia must have a strong economic plan as this will resolve the 
financial issues that will rise in embarking the exploration.

\section{Conclusion}

Malaysia is embarking on deep seabed mining exploration. However, many issues need to be resolved before Malaysia can consider to partake in deep seabed mining activities. These issues include the legal aspects, the impact on the environment, technology, and return to investment. Therefore, a special committee which comprises of researches, government and stakeholders including the affected populace should be established. This is vital as the decision to explore the deep seabed minerals is not simple. It involves a lot of effort, work and views from different perspectives.

Apart from that, many aspects of deep seabed mining have to be considered including financial implications and the role of the government as an ultimate regulator and administrator. Without the support from the government, this exploration plan will not be successful.

After the procedures to explore the deep seabed minerals has been fulfilled, then Malaysia have to establish its own deep seabed mining laws. It is essential to have comprehensive governance framework including policies and administrative measures to ensure effective implementation and enforcement particularly in matters related to the health of the marine environment.

If the plan is drafted thoroughly, and the technology and the financial issues can be resolved, only then would Malaysia be ready to embark on extensive deep seabed mining.

\section{Acknowledgements}

The author would like to acknowledge the guidance and assistance provided by her Master's supervisors, Professor Dr. Wan Izatul Asma Bt Wan Talaat of the Institute of Oceanography and Environment (INOS), Universiti Malaysia Terengganu and Dr. Mohd Hazmi Mohd Rusli of the Faculty of Syariah and Law, Universiti Sains Islam Malaysia during the preparation of this article. However, the submitting author accepts responsibility for any errors in this article.

\section{References}

Abdul Ghafur Hamid @ Khin Mau Seng. (2011). Public international law: A practical approach (3rd ed.). Selangor: Thomson Reuters.

Allsopp, M., Miller, C., Atkins, R., Rocliffe, S., Tabor, I., Santillo, D., \& Johnston, P. (2013). Review of the current state of development and the potential for environmental impacts of seabed mining operations. Greenpeace Research Laboratories Technical Report (Review), 3-2013. Retrieved from: https://www.oceanfdn.org/sites/default/files/seabed-mining-tech-review-2013.pdf

Birney, K., Griffin, A., Gwiazda, J., Kefauver, J., Nagai, T., \& Varchol, D. (2006). Potential deep-sea mining of seafloor massive sulfides: A case study in Papua New Guinea. Donald Bren School of Environmental Science and Management Thesis. Retrieved from: http://shipwreck.net/pdf/VentsThesis.pdf

Burger, S. (2014, February). Development of deep-seabed mining rules under way. Mining Weekly. Retrieved from http://www.deepseaminingoutofourdepth.org

Dyment, J., Lallier, F., Le Bris, N., Rouxel, O., Sarradin, P.-M., Lamare, S., Coumert, C., Morineaux, M., Tourolle, J. (2014). Collective sceintific expertise: Environmental impacts of deep-sea mining. Ifremer. Retrieved from: http://www.developpement-durable.gouv.fr/IMG/pdf/ESCO-resume-EN.pdf

Egede, E. (2005). Deep seabed regime: Africa's contribution to its evolution and system of mining (Doctoral dissertation, Cardiff University). Retrieved from: http://orca.cf.ac.uk/55999/1/U584744.pdf

Egorov, L., Elosta, H., Kudla, N. L., Shan, S., \& Yang, K. K. (2012). Sustainable seabed mining: guidelines and a new concept for Atlantis II Deep. Retrieved from http://eprints.soton.ac.uk/349891/1/_soton.ac.uk_ude PersonalFiles_Users_asv1a09_mydocuments_FSI\%20Admin\%20Files_LRET\%20Collegium_LRET\%2020 12_AAAA\%20The\%20LRET\%202012\%20Books_LRET\%20Collegium\%202012\%20Final\%20Version\%2 01-5_Book_vol_4.pdf

Guntrip, E. (2003). The common heritage of mankind: An adequate regime for managing the deep seabed? Melbourne Journal of International Law, 4, 376. Retrieved from http://www.austlii.edu.au/au/journals/ MelbJIL/2003/2.html

Hein, J. R., Mizell, K., Koschinsky, A., \& Conrad, T. a. (2013). Deep-ocean mineral deposits as a source of critical metals for high- and green-technology applications: Comparison with land-based resources. Ore Geology Reviews, 51, 1-14. http://doi.org/10.1016/j.oregeorev.2012.12.001 
Hunter, T., \& Taylor, M. (2013). Deep seabed mining in the South Pacific: A background paper. Centre for International Minerals and Energy Law. Retrieved from https://intranet.law.uq.edu.au/old-site/law.uq.edu. $\mathrm{au} /$ documents/cimel/Deep-Sea-Bed-Mining-in-the-South-Pacific.pdf

Lee, E. T. H. (2013). Scope for improvement: Malaysia's oil and gas sector. Research For Social Advancement (REFSA). Retrieved from http://refsa.org/wp/wp-content/uploads/2013/07/OG-Scoping-Report-Malaysiafinal-20130701.pdf

Mahapatra, R, \& Chakravartty, A. (2014). Mining at deep sea. Down to Earth. Retrieved from http://www.downtoearth.org.in

Markussen, J. M. (1994). Deep seabed mining and the environment: Consequences, perceptions, and regulations. Green Globe Yearbook of International Co -Operation on Environment and Development, 1994, 31-39. Retrieved from: http://citeseerx.ist.psu.edu/viewdoc/download?doi=10.1.1.631.7721\&rep=rep1\&type=pdf

Mavani, E. (2012). What happens when our oil wells run dry? Free Malaysia Today. Retrieved from http://www.freemalaysiatoday.com

Othman, J., \& Jafari, Y. (2012). Accounting for depletion of oil and gas resources in Malaysia. Natural Resources Research, 21(4), 483-494. https://doi.org/10.1007/s11053-012-9192-2

Ooi, I. U. (2007). Malaysian Maritime Enforcement Agency Act 2004: Malaysia's legal response to the threat of maritime terrorism. The. Austl. \& NZ Mar. LJ, 21, 70. Retrieved from http://www.austlii.edu.au/au/journals/ ANZMarLawJ1/2007/6.html

Schmidt, C. W. (2015). Going deep: Cautious steps toward seabed mining. Environmental Health Persepctives, 123(9), 1-8. http://doi.org/10.1080/10417940600681475

Sterk, R., \& Stein, J. K. (2015, February). Seabed mineral resources: A review of current mineral resources and future developments. Paper presented at the Deep Sea Mining Summit, Aberdeen, Scotland (pp. 1-27). Retrieved from https://static1.squarespace.com/static/5488e0c0e4b0d6bada814368/t/550dc69ce4b0299913b 6c1e9/1426966172229/150209SterkStein2015-SeabedMineralResources-AReviewofCurrentMineralResour cesandFutureDevelopments2.pdf

Vincent, J. R. (1997). Resource depletion and economic sustainability in Malaysia. Environment and Development Economics, 2(1), 19-37. http://doi.org/10.1017/S1355770X97000107

Warner, R. (2006). Protecting the diversity of the depths: Strengthening the international law framework, (Doctoral dissertation, University of Sydney, Sydney, Australia). Retrieved from: https://ses.library.usyd.edu.au/bitstream/2123/1304/2/02whole.pdf

World Economic Forum (2016). Toward Transparency and Best Practices for Deep Seabed Mining: An Initial Multistakeholder Dialogue. Proceedings of the Conference on Transparency and Best Practices for Deep Seabed Mining (pp. 1-10). Bellagio, Italy: World Economic Forum. Retrieved from http://dosi-project.org

\section{Copyrights}

Copyright for this article is retained by the author(s), with first publication rights granted to the journal.

This is an open-access article distributed under the terms and conditions of the Creative Commons Attribution license (http://creativecommons.org/licenses/by/4.0/). 